\title{
Review
}

\section{Pollutant removal-oriented yeast biomass production from high-organic-strength industrial wastewater: A review}

\author{
Min Yang ${ }^{b}$, Shaokui Zheng ${ }^{a, *}$ \\ a School of Environment, MOE Key Laboratory of Water and Sediment Sciences/State Key Lab of Water Environment \\ Simulation, Beijing Normal University, Beijing 100875, China \\ ${ }^{\mathrm{b}}$ Research Center for Eco-environmental Sciences, Chinese Academy of Sciences, Beijing 100085, China
}

\section{A R T I C L E I N F O}

\section{Article history:}

Received 25 January 2013

Received in revised form

23 February 2014

Accepted 12 March 2014

Available online 2 April 2014

\section{Keywords:}

Biomass production

Yeast

High-organic-strength industrial

wastewater

Yeast treatment process

Biocontrol

\begin{abstract}
A B S T R A C T
Microbial single-cell-protein (SCP) production from high-organic-strength industrial wastewaters is considered an attractive method for both wastewater purification and resource utilization. In the last two decades, pollutant removal-oriented yeast SCP production processes, i.e., yeast treatment processes, have attracted a great deal of attention from a variety of research groups worldwide. Different from conventional SCP production processes, yeast treatment processes are characterized by higher pollutant removal rates, lower production costs, highly adaptive yeast isolates from nature, no excess nutrient supplements, and are performed under non-sterile conditions. Furthermore, yeast treatment processes are similar to bacteria-dominated conventional activated sludge processes, which offer more choices for yeast SCP production and industrial wastewater treatment. This review discusses why highly adaptive yeast species isolated from nature are used in the yeast treatment process rather than commercial SCP producers. It also describes the application of yeast treatment processes for treating high-carboxyhydrate, oil-rich and high-salinity industrial wastewater, focusing primarily on high-strength biodegradable organic substances, which usually account for the major fraction of biochemical oxygen demand. Also discussed is the biodegradation of xenobiotics, such as color (including dye and pigment) and toxic substances (including phenols, chlorophenols, polycyclic aromatic hydrocarbons, etc.), present in industrial wastewater. Based on molecular information of yeast community structures and their regulation in yeast treatment systems, we also discuss how to maintain efficient yeast species in yeast biomass and how to control bacterial and mold proliferation in yeast treatment systems.
\end{abstract}

() 2014 Elsevier Ltd. All rights reserved.

\footnotetext{
* Corresponding author. Tel.: +861058809266.

E-mail address: zsk@bnu.edu.cn (S. Zheng). http://dx.doi.org/10.1016/j.biombioe.2014.03.020 0961-9534/@ 2014 Elsevier Ltd. All rights reserved.
}

\section{Introduction}

Yeasts are a group of unicellular fungi widely distributed in nature, most of which belong to two separate phyla: the Ascomycota and the Basidiomycota. Yeasts have played 
important roles in the fermentation and food industries for thousands of years. Their obligatory acidophilic properties suggest that the fungi would not act as an opportunistic pathogen [1]. The protein extracted from yeast biomass, single cell protein (SCP), can replace costly conventional proteinaceous sources (e.g., soymeal and fishmeal) for animal feeds.

High-organic-strength industrial wastewaters often represent a significant loss of resources and causes serious pollution problems [2]. SCP production from these wastewaters is an attractive approach to both wastewater purification and resource utilization [3]. In most cases, the analyzed SCP composition mainly includes protein concentration, amino acid profiles, vitamins, carbohydrates, fats, and nucleic acids [4]. Since World War II, many yeast species have been used to produce SCPs from industrial wastewaters, a process that has been very important for numerous chronically malnourished people worldwide [5]. However, the conventional SCP process requires a pure yeast strain, expensive sterilization processes [6], optimized culture conditions (e.g., pH adjustment, extra nutrient supplement $[\mathrm{N}, \mathrm{P}, \mathrm{Mg}, \mathrm{Ca}, \mathrm{Fe}, \mathrm{Zn}, \mathrm{Cu}, \mathrm{Mn}$, and vitamins] [7], dilution rates [8]), and an air saturation of $\geq 20 \%$ dissolved oxygen (DO) by aeration [9] to achieve the maximum yeast biomass production. This results in high SCP production costs, low organic removals, and high nutrient residues that require post-treatment to control their discharge.

After the 1980s, numerous highly adaptive yeast strains for various industrial wastewaters have been isolated from a variety of sources (e.g., wastewater-contaminated soil, activated sludge) to replace commercial SCP yeast species due to their higher pollutant removal performances [10]. The pollutant removal-oriented SCP production processes, i.e., yeast treatment process, is characterized by higher pollutant removals, lower production costs, isolated yeast species, no excess nutrient supplements, and is performed under nonsterile conditions in a system similar to bacteria-dominated conventional activated sludge process (ASP) $[6,11,12]$. Its organic loading amounts to at least $15 \mathrm{~kg} \cdot \mathrm{m}^{-3} \cdot \mathrm{d}^{-1}$ chemical oxygen demand (COD) [13], which is nearly 10 times higher than conventional ASPs, thus offering more choices for yeast SCP production and industrial wastewater treatment.

\section{Yeast species used in yeast treatment process}

For conventional SCP processes, higher SCP production and protein content, and more plentiful and balanced amino acids essential for animal feed tend to make the selected yeast species or strain more attractive [14]. The most popular SCP yeast species are from the genera Candida, Hansenula, Pichia, Torulopsis and Saccharomyces [4]. In many cases, Candida utilis is frequently used for biomass production from a variety of carbon sources due to its high SCP production and specific growth rate $[14,15]$. However, the yeast species found in industrial wastewater treatment systems represent 48 taxa belonging to 21 different genera, of which the most frequent populations are from the genera Rhodotorula, Candida, Trichosporon, Pichia and some unidentified Ascomycetes [16]. This suggests that those commercial SCP yeast species may not be the most suitable for yeast treatment processes. For example,
Candida langeronii appeared superior to C. utilis for biomass production from hemicellulose hydrolysate since the latter cannot utilize L-arabinose and grow at $42{ }^{\circ} \mathrm{C}$ [14].

Yeast strains of differing origins have different pollutant removal potentials [17], and isolated yeast strains obtained by spontaneous selection pressure in wastewater often reduce more COD and produce more yeast biomass than conventional SCP producers $[10,18]$. Furthermore, specific yeast species often selectively utilize preferential carbon sources prior to other carbon sources [14], or use metabolic byproducts generated by other yeast species in mixed culture [2]. In other words, mixed yeast cultures often result in higher biomass yield and greater pollutant removal from industrial wastewater containing a variety of carbon sources [2,11]. Therefore, yeast treatment processes use highly adaptive mixed yeast isolates rather than commercial SCP producers to treat corresponding industrial wastewaters.

\section{High-organic-strength wastewater treatment}

Yeasts show high tolerance to low $\mathrm{pH}$, high salinity, highcontent organics, antibiotics, and sterilizers [19], and can metabolize various carbon substrates, including sugars (e.g., glucose, sucrose and maltose), biopolymers (e.g., starch, cellulose, hemicellulose and pectin), pentoses, methanol, alcohols, polyols, hydrocarbons, fatty acids and organic acids [7]. Industrial wastewaters are often highly acidic $(\mathrm{pH}<5)$ and require a $\mathrm{pH}$ adjustment to 6.5-7.6 to reduce $\mathrm{pH}$ toxicity against bacteria for ASPs or anaerobic processes [20]. Following the yeast treatment process, the $\mathrm{pH}$ levels of these acidic industrial wastewaters often rise to neutral $[6,10,21]$, which reduces wastewater treatment costs and facilitates subsequent ASPs. Therefore, yeast treatment processes appear to be more suitable and cost-effective for the treatment of acidic, oily, high-salinity, ammonia- or sulfate-ridden high-organic-strength industrial wastewaters that are not suitable for direct treatment by anaerobic processes. In addition to soluble organic substances, most yeast directly assimilate ammonium ions, urea, inorganic phosphates and sulphates [7]. However, higher nitrogen removal for the yeast system compared to the bacterial system has been attributed to higher nutrient (nitrogen and phosphorous) uptake in the yeast cells compared to bacterial cells [22]. In recent years, an in vitro detectable polyphosphate-synthesizing activity has been characterized in extracts of the yeast Candida humicola, and its properties were similar to those of a range of bacterial polyphosphate kinase enzymes [23].

\subsection{High-carbohydrate wastewater}

Yeasts can metabolize various carbon substrates; however, they mainly utilize sugars (e.g., glucose, sucrose and maltose) [7]. Therefore, the concept of using yeasts to bioconvert highcarbohydrate wastewaters has long attracted the attention of SCP researchers. High-carbohydrate wastewater for SCP processes is produced widely in many food processing industries [13], e.g., starch processing wastewater [24], waste cassava starch hydrolysate [9], deproteinized whey [25], and defatted 
rice polishings [5]. Recent studies have examined different vegetable processing wastewaters for yeast biomass production (Table 1), e.g., water extracts of cabbage and watermelon $[26,27]$, pineapple cannery effluent $[8,28]$, silage effluent [10], sugar cane bagasse hydrolysate [14], waste capsicum powder [15], and bamboo wastewater [29]. For example, a filamentous yeast strain (Galactomyces geotrichum) was isolated from silage effluent, and its ability to grow on and purify silage effluent was assessed in comparison with a strain of $C$. utilis. The yeast isolatefinally achieved 91-95\% COD removals and gave consistently higher biomass yields than $C$. utilis, producing a maximum of $\sim 9 \mathrm{~g} \cdot \mathrm{L}^{-1}$ [10]. Furthermore, wastewaters from various fermentation processes, e.g., pharmaceutical, alcoholic [30], butanol [31], vitamin, glutamate [6] industry, etc., also contained sugar residues as the main COD constituent. An isolated yeast, identified as Pichia anomala, achieved maximum COD reduction (81\%) from ergot alkaloid production wastewater [18]. The binary yeast isolates Candida halophila and Rhodotorula glutinis achieved $85 \%$ COD reduction and $96 \%$ sugar reduction from glutamate fermentation wastewater [32].

\subsection{Oil-rich wastewater}

Considerable quantities of oil-containing wastewater are released from the food processing industries (e.g., slaughterhouse, dairy, and oil manufacturing) and tanneries. For example, olive mill wastewater (OMW) treatment has become a critical environmental challenge for the Mediterranean countries, which account for approximately $95 \%$ of the world olive production [17]. In these edible oil manufacturing plants, a considerable amount of fatty acid in raw vegetable oil is separated from glyceride through a water washing process and then discarded as oil-rich industrial wastewater [33]. Dairy wastewaters often contain high levels of fats and esters (i.e., essentially triglycerides consisting of straight-chain fatty acids attached to glycerol) and their hydrolytic products (i.e., long chain fatty acids) [34]. A wide spectrum of different types of yeasts, e.g., Candida tropicalis, Candida rugosa, Candida lipolytica and Saccharomyces lipolytica, are able to grow on lipids [35]. In Japan, nine strains of yeasts capable of decomposing oil were isolated to directly treat soybean oil manufacturing wastewater (10 $000 \mathrm{mg} \cdot \mathrm{L}^{-1}$ oil) with no pretreatment and to achieve an effluent with $100 \mathrm{mg} \cdot \mathrm{L}^{-1}$ oil in an 1-year pilot operation [11]. In comparison with other yeast isolates (Rhodotorula rubra, Candida boidinii, Trichosporon cutaneum), C. utilis had the greatest oil uptake rate and highest specific growth rate [3]. Ten isolated yeast strains stably removed $>89 \%$ COD and $>99 \%$ oil from vegetable oil-containing wastewater $\left(15 \mathrm{~g} \cdot \mathrm{L}^{-1} \mathrm{COD}\right.$ and $10 \mathrm{~g} \cdot \mathrm{L}^{-1}$ oil) [36].

\subsection{High-salinity wastewater}

Vegetable, tanning, fermentation and seafood processing industries often generate large quantities of saline high-organicstrength wastewater. The majority of bacterial species tend to dehydrate and disintegrate due to the high osmotic pressure differences between the protoplasm and the ambient high saline conditions, which severely inhibits growth and performance of bacterial systems [22]. It is reported that application of salt-tolerant bacteria (e.g. Halobacter halobium) in ASPs resulted in better treatment performances at salt contents above $2 \%$ [37]. As an alternative to salt-tolerant bacteria, osmotolerant yeast culture was more efficient for aerobic treatment of high salinity wastewater compared to bacterial culture [22]. For example, the osmotolerant yeast, Pichia guilliermondii, was selected from 70 yeast isolates to produce SCP from sugar-rich waste brine from a kimchi factory containing $10 \% \mathrm{NaCl}$, and removed approximately $90 \%$ biochemical oxygen demand (BOD) within $24 \mathrm{~h}$ [38]. Six strains of yeast, Saccharomyces sp., Pichia sp., Rhodotorula sp., Candida sp., Kluyveromyces sp. and Trichospora sp., grew well in lettuce brine from the vegetable fermentation industry under aerobic conditions [21]. The binary yeast isolates C. halophila and Rhodotorula glutinis achieved a constant COD removal of $>80 \%$ from the wastewater (salinity 12\%) during 2-months of continuous operation of a fixed-bed reactor [6]. The mechanisms underlying the adaptation of various yeasts to salt stress involve the accumulation of osmotically active compounds (mainly glycerol) to counterbalance an increased external osmotic pressure and the modification of plasma membrane transport systems to extrude $\mathrm{Na}^{+}$from the cell [39].

\section{Xenobiotic biodegradation by yeast}

Besides high-strength biodegradable organic substances, which usually contribute the major fraction of the BOD, many

Table 1 - Yeast SCP production from high-carbohydrate wastewaters discharged from vegetable processing industries.

\begin{tabular}{|c|c|c|c|c|c|}
\hline Wastewater origins & Countries & $\begin{array}{c}\text { Reducing } \\
\operatorname{sugar}\left(g \cdot L^{-1}\right)\end{array}$ & Yeast species & $\begin{array}{c}\text { Biomass } \\
\text { production }\left(g \cdot \mathrm{L}^{-1}\right)\end{array}$ & $\begin{array}{c}\text { Protein } \\
\text { content }(\%)\end{array}$ \\
\hline Waste Chinese cabbage [26] & South Korea & 18.5 & $\begin{array}{l}\text { Candida utilis, Pichia stipitis, } \\
\text { Kluyveromyces marxianus, } \\
\text { Saccharomyces cerevisiae }\end{array}$ & $6-10$ & $35-44$ \\
\hline $\begin{array}{l}\text { Cabbage, watermelon, } \\
\text { green salads, and } \\
\text { tropical fruits [27] }\end{array}$ & Singapore & $1.4-8.9^{a}$ & Saccharomyces cerevisiae & $6-8$ & $40-45$ \\
\hline Pineapple cannery waste [8] & India & 7.5 & Candida utilis & 3 & \\
\hline Silage effluent [10] & UK & $40.5^{b}$ & Galactomyces geotrichum & 9 & 16 \\
\hline Waste capsicum powder [15] & China & $12-18$ & $\begin{array}{l}\text { Candida utilis, Candida tropicalis, } \\
\text { Saccharomyces cerevisiae }\end{array}$ & $7-14$ & $25-48$ \\
\hline Bamboo wastes [29] & China & $\sim 40$ & Candida utilis & 19 & \\
\hline
\end{tabular}


industrial wastewaters contain xenobiotics, such as color substances (including dye and pigment) and toxic xenobiotics (including phenols, chlorophenols, antibiotics, polycyclic aromatic hydrocarbons (PAHs), etc.). While dyes are commonly used in food and textile dyeing/finishing industries, other color substances are also produced by various industrial processes, for example melanoidin pigment, a dark brown pigment found in the molasses wastewater [40]. The presence of very small amounts of color substances in wastewater (less than $1 \mathrm{mg} \cdot \mathrm{L}^{-1}$ for some dyes) is highly visible and affects the aesthetic merit, water transparency and gas solubility. Furthermore, the OMW are very phytotoxic and possess strong antimicrobial activities principally due to phenolic compounds, such as tyrosol and hydrotyrosol [17]. Avermectin fermentation wastewater contains toxic avermectins, macrolytic lactones as pesticides and antiparasitic drugs that inhibit anaerobic bacteria [19]. Methods for BOD removal from these industrial wastewaters are fairly well established; however, toxic xenobiotics are generally resistant to microbial degradation due to their synthetic origin and complex aromatic molecular structures [40]. Therefore, the removal of these xenobiotics from wastewaters is often more important than the removal of soluble biodegradable organic substances. A variety of yeast species are known to secrete enzymes capable of degrading xenobiotic compounds. The proliferation of yeast cells in industrial wastewater is often accompanied by a concomitant xenobiotic biodegradation [41], e.g., color substances [40,42-45], phenol- and chlorophenol-related substances [46-50], PAHs [51,52], and other toxic xenobiotics $[19,41]$.

The final yeast SCP product should not only be nutritious, but toxins, hydrocarbons, petroleum or heavy metals accumulated during the course of growth should be removed for the SCP to pass all toxicity tests and to be commercialized as a food product $[4,53]$. Since some high-organic-strength industrial wastewaters can contain xenobiotics, and the yeast biomass from yeast treatment process contains bacterial cells, necessary toxicity measurements (e.g., feed experiments [54]) should be considered to assure the suitability of the resulting yeast SCP for animal feed. Additionally, the yeast SCP from some fermentation wastewater containing toxic fermentation products (e.g., antibiotics) can be reused as raw material or a nitrogen source for commercial fermentation of identical fermentation products to avoid the side effect of those toxic residues.

\subsection{Color substances}

Although several yeasts may remove dyes through biosorption mechanisms [42], there have been numerous reports on decolorization by yeast through biodegradation. For example, two yeast isolates, Debaryomyces polymorphus and C. tropicalis, may produce manganese dependant peroxidase and decolorize six azo dyes and one anthraquinone dye by cometabolism [43]. Among the 2402 strains of yeast isolates from various sources, a strain identified as Issatchenkia orientalis showed the highest potential for decolorization of anaerobictreated molasses wastewater with melanoidin pigment, COD and BOD removals of $91 \%, 80 \%$ and $77 \%$, respectively, at $30{ }^{\circ} \mathrm{C}$ and $\mathrm{pH} 5.0$ during a 7 day batch culture [40]. Subsequently, this strain provided a constant decolorization yield about $70 \%$ during 3 replacement cycles [40]. The yeast Candida zeylanoides degraded a number of simple azo dyes with color removals ranging from $44 \%$ to $90 \%$ [44]. The Kluyveromyces marxianus IMB3 decolorized Remazol Black-B dye with the maximum color removal of $98 \%$ at $37{ }^{\circ} \mathrm{C}$ and $\mathrm{pH} 3.0-5.5$ due to biosorption to the yeast cells rather than a metabolic reaction [45].

\subsection{Phenol- and chlorophenol-related substances}

Two wild type strains of Yarrowia lipolytica could grow in OMW with $19 \mathrm{~g} \cdot \mathrm{L}^{-1}$ of COD and approximately $800 \mathrm{mg} \cdot \mathrm{L}^{-1}$ of total phenols, leading to $80 \%$ COD degradation and $70 \%$ total phenol reduction [46]. A fluidized bed reactor loaded with $C$. tropicalis immobilized onto granular activated carbon was capable of efficiently removing phenol as the sole carbon source at volumetric loading rates as high as $60 \mathrm{mg} \cdot \mathrm{L}^{-1} \cdot \mathrm{h}^{-1}$ phenol [47]. A total of 32 cold-adapted, psychrophilic and cold-tolerant yeast isolates from alpine habitats, including Cryptococcus terreus, Cryptococcus terricola, Rhodosporidium lusitaniae, Rhodotorula creatinivora, Rhodotorula ingeniosa, Mastigobasidium intermedium, and Sporobolomyces roseus, were able to degrade phenol and 18 phenol-related mono-aromatic compounds at low temperatures [48]. A pure culture of $C$. tropicalis isolates could degrade $2000 \mathrm{mg} \cdot \mathrm{L}^{-1}$ phenol and $280 \mathrm{mg} \cdot \mathrm{L}^{-1} \mathrm{~m}$-cresol within 66 and $52 \mathrm{~h}$, respectively, and the presence of $\mathrm{m}$-cresol significantly inhibited phenol biodegradation while a low phenol concentration accelerated the assimilation of $\mathrm{m}$-cresol [49]. Among the most investigated yeast strains capable of degrading phenol and chlorophenol (C. tropicalis, Candida maltosa; Trichosporon oivide, Trichosporon cutaneum, and Rhodotorula glutinis), C. tropicalis is a hydrocarbonoclastic yeast capable of metabolizing phenol, resorcinol, quinol, hydroxyquinol, catechol, and to a lesser extent protocatechuate, $\mathrm{p}$ cresol, m-chlorophenol, and p-chlorophenol via the b-ketoadipate pathway by an inducible-enzyme system [50].

\subsection{PAHs}

Pichia anomala, isolated from soil contaminated with crude oil, degraded four PAHs (naphthalene, dibenzothiophene, phenanthrene and chrysene) both alone and in combination [51]. Five PAHs-degrading yeast isolates from the oil-contaminated soil in Jidong Oilfield in China, including C. maltosa-like, Pichia guilliermondii, Rhodotorula dairenensis, Sporidiobolus salmonicolor and Pichia anomala, efficiently degraded $\sim 99 \%$ of low molecular weight PAHs and $\sim 89 \%$ of high molecular weight PAHs at room temperature within 6 weeks [52].

\subsection{Other toxic xenobiotics}

The methylotrophic yeast Hansenula polymorpha can utilize formaldehyde at concentrations up to $1750 \mathrm{mg} \cdot \mathrm{L}^{-1}$, levels toxic to most microorganisms, for treating methanol and formaldehyde-containing chemical industry wastewater through methylotrophic pathway reactions [41]. C. tropicalis, which was screened from avermectin fermentation wastewater and showed tolerance to avermectins residue, removed $67 \%$ COD and $99 \%$ avermectins [19]. 


\section{Biocontrol of yeast treatment system}

Molecular fingerprinting techniques, including polymerase chain reaction-based denaturing gradient gel electrophoresis [55], cloning and sequencing of rRNA genes [56,57], and fluorescent in situ hybridization-flow cytometry [20,56,58], allow for accurate identification, quantification and community structure analyses of the microbial population. The rapid development of these methods in the past two decades provides new insight into the microbial community structure and thus favored biocontrol in yeast treatment systems.

A large loss of yeast species and even biomass washout is often observed during the transformation from batch culture to a continuous culture [11,12], which influences treatment performance in some cases [12]. For example, of the five isolated yeast species Rhodotorula rubra, C. tropicalis, C. utilis, C. boidinii and Trichosporon cutaneum, only $C$. tropicalis ultimately remained in the aeration tank, possibly due to its optimal settle-ability [12]. Among the ten yeast species isolated from soil contaminated by wastewater, only C. lipolytica, C. tropicalis, and $C$. halophila were dominant in the system, which was determined by the surface hydrophobicity and emulsification ability of yeast cells rather than COD removals, biomass yield, cell settle-ability and cell flocculation ability [36]. Therefore, the application of efficient yeast isolates does not imply their presence and action inside a wastewater treatment system. Furthermore, the internal relationships between the operational parameters and yeast community structure are of considerable importance for the treatment performance. Several clone library analyses revealed that DO level (aerobic and microaerobic) was a critical factor affecting the yeast community structure and treatment performance in yeast treatment systems $[56,57]$. The aerobic DO level $\left(>2 \mathrm{mg} \cdot \mathrm{L}^{-1}\right)$ resulted in more determined yeast species, poor biomass settling, and higher COD removals, while the microaerobic DO level $\left(<0.5 \mathrm{mg} \cdot \mathrm{L}^{-1}\right)$ effectively restored the microbial biomass settlement, as well as produced unacceptable COD removals and fewer determined yeast species [56]. The influent COD level and hydraulic retention time (HRT), two primary components of the influent COD loading rate, have different effects on the structure and function of the yeast community when a higher influent COD loading rate is achieved [55]. Therefore, a higher influent COD level at identical HRT supported more yeast species and thus the metabolism of a greater variety of carbon sources, while a shorter HRT at identical influent COD level supported fewer yeast species and thus the metabolism of fewer carbon sources [55].

Because yeast treatment systems are generally open systems, the substrate also promotes the growth of bacterial or mold species present in the mixed liquor when the yeast species propagate continuously. The propagation of a specific yeast strain in the yeast treatment system is based on free competition among different microorganisms [22]. Therefore, the major challenge for yeast treatment processes is to properly design and control operational conditions to guarantee a yeast-dominated biomass, as well as good biomass settling under non-sterile conditions. Because sterilization for conventional SCP process is expensive, the fact that yeast can grow at low $\mathrm{pH}$ can be used to: (i) Sterilize the water at relatively low temperatures, (ii) prohibit contaminating bacteria from growing, and (iii) provide sufficient environmental selection pressure in a continuous system to direct a complex microflora towards yeast domination [35]. Therefore, an acidic $\mathrm{pH}(<6)$ is generally used for yeast treatment processes to maximize yeast growth and limit bacterial growth under the non-aseptic conditions $[11,20,55,59]$. However, based on fluorescent in situ hybridization-flow cytometry analyses, Zheng et al. [20] found that it was difficult to achieve yeastdominated biomass in continuous-flow systems at low COD loadings (e.g., $2 \mathrm{~kg} \cdot \mathrm{m}^{-3} \cdot \mathrm{d}^{-1} \mathrm{COD}$ ), regardless of the acidic $\mathrm{pH}$ levels, while acidic $\mathrm{pH}$ was sufficient to achieve yeastdominated biomass in a batch culture. In other words, the yeast treatment process should be conducted with both acidic $\mathrm{pH}$ and high COD loading (e.g., 8.7 and $21.0 \mathrm{~kg} \cdot \mathrm{m}^{-3} \cdot \mathrm{d}^{-1} \mathrm{COD}$ ) levels as prerequisites [20]. If yeast cells are larger than bacterial cells, producing a lower surface-to-volume ratio, lower substrate adsorption/uptake efficiency at low substrate concentrations or loading may result.

Although bacteria have difficulty competing with yeast at acidic $\mathrm{pH}$, molds do not encounter this problem [35]. However, most molds are extremely sensitive to $\mathrm{CO}_{2}$ and even $10 \% \mathrm{CO}_{2}$ is sufficient to stop their growth in a competitive situation [35]. Furthermore, many yeast species, including Candida fennica, Candida pelliculosa, Candida silvicultrix, Pichia anomala, Pichia burtonii, Pichia farinosa and Pichia membranifaciens have validated their mold biocontrol ability, i.e., strongly inhibiting inoculated and endogenous molds (e.g., Penicillium roqueforti and gray mold (Botrytis cinerea)) [60]. In fact, few reports are available on mold growth and dominance in yeast treatment systems. Many clone library analyses revealed that all clonal fungal sequences inside yeast treatment systems were of yeast rather than mold origin [56]. In previous studies, the mold Geotrichum candidum was suspected to successfully propagate in yeast treatment systems and result in poor settling and deteriorated treatment performance [33]. However, subsequent investigations have demonstrated that these filamentous fungal species obtained in yeast biomass could be specific yeast species with two different cell morphologies (conidia and hyphae) [56].

\section{Conclusion}

The yeast treatment process uses highly adaptive mixed yeast isolates under non-sterile conditions rather than commercial SCP producers under sterile conditions, which achieves higher pollutant removals and lower SCP production costs. The process appears to be cost-effective for the removal of highstrength biodegradable organic substances from acidic, oily, high-salinity, ammonia- or sulfate-ridden high-organicstrength industrial wastewaters that are not suitable for direct treatment by anaerobic processes. The proliferation of yeast cells in these industrial wastewater is often accompanied by a concomitant xenobiotic biodegradation including color substances and toxic xenobiotics. In the ASP-like open system, the internal relationships between the operational parameters and yeast community structure are of considerable importance for the successful application of efficient yeast isolates. Furthermore, in continuous-flow yeast treatment 
systems, operating at both acidic $\mathrm{pH}$ and high COD loading levels inhibits the growth of bacterial species present in the mixed liquor while few molds grow and dominate in yeast biomass possibly due to the presence of $\mathrm{CO}_{2}$ and/or some yeast species with mold biocontrol ability.

\section{Acknowledgment}

This study was supported by the Natural Science Foundation of China (51378066 and 21077011) and the New Century Excellent Talents in University (NECT-11-0044).

\section{R E F E R E N C E S}

[1] Nigam P. Process selection for protein-enrichment: fermentation of the sugar industry by products molasses and sugar beet pulp. Process Biochem 1994;29(5):337-42.

[2] Cristiani-Urbina E, Netzahuatl-Munoz AR, ManriquezRojas FJ, Juarez-Ramirez C, Ruiz-Ordaz N, Galindez-Mayer J. Batch and fed-batch cultures for the treatment of whey with mixed yeast cultures. Process Biochem 2000;35:649-57.

[3] Zheng S, Yang M, Yang ZF. Biomass production of yeast isolate from salad oil manufacturing wastewater. Bioresour Technol 2005;96:1183-7.

[4] Anupama PR. Value-added food: single cell protein. Biotechnol Adv 2000;18:459-79.

[5] Rajoka MI, Kiani MAT, Khan S, Awan MS, Hashmi AS. Production of single cell protein from rice polishing using Candida utilis. World J Microb Biot 2004;20:297-301.

[6] Yang Q, Yang M, Zhang S, Lv W. Treatment of wastewater from a monosodium glutamate manufacturing plant using successive yeast and activated sludge systems. Process Biochem 2005;40:2483-8.

[7] Bekatorou A, Psarianos C, Koutinas AA. Production of food grade yeasts. Food Technol Biotech 2006;44:407-15.

[8] Nigam JN, Kakati MC. Optimization of dilution rate for the production of value added product and simultaneous reduction of organic load from pineapple cannery waste. World J Microb Biot 2002;18(4):301-5.

[9] Ejiofor AO, Chisti Y, MooYoung M. Culture of Saccharomyces cerevisiae on hydrolyzed waste cassava starch for production of baking-quality yeast. Enzyme Microb Tech 1996;18(7):519-25.

[10] Arnold JL, Kanpp JS, Johnson CL. The use of yeasts to reduce the polluting potential of silage effluent. Water Res 2000;34(15):3699-708.

[11] Chigusa K, Hasegawa T, Yamamoto N, Watanabe Y. Treatment of wastewater from oil manufacturing plant by yeasts. Wat Sci Tech 1996;34(11):51-8.

[12] Zheng S, Yang M, Park YH, Liu F. Washout of a yeast population during continuous treatment of salad-oilmanufacturing wastewater. Bioresour Technol 2003;86:235-7.

[13] Zhang YM, Rittmann BE, Wang JL, Sheng YH, Yu JT, Shi HC, et al. High-carbohydrate wastewater treatment by IAL-CHS with immobilized Candida tropicalis. Process Biochem 2005;40:857-63.

[14] Nigam JN. Cultivation of Candida langeronii in sugar cane bagasse hemicellulosic hydrolyzate for the production of single cell protein. World J Microb Biot 2000;16:367-72.

[15] Zhao G, Zhang W, Zhang G. Production of single cell protein using waste capsicum powder produced during capsanthin extraction. Lett Appl Microbiol 2010;50:187-91.
[16] Yang Q, Angly FE, Wang Z, Zhang H. Wastewater treatment systems harbor specific and diverse yeast communities. Biochem Eng J 2011;58-59:168-76.

[17] Lanciotti R, Gianotti A, Baldi D, Angrisani R, Suzzi G, Mastrocola D, et al. Use of Yarrowia lipolitica strains for the treatment of olive mill wastewater. Bioresour Technol 2005;96:317-22.

[18] Recek M, Raspor P. Yeast growth potential and COD reduction in waste water from ergot alkaloid production. Food Technol Biotech 1999;37(3):159-63.

[19] Wang XX, Zhao ZH, Chang TS, Liu JG. Yeast screening from avermectins wastewater and investigation on the ability of its fermentation. Bioproc Biosyst Eng 2011;34:1127-32.

[20] Zheng S, Zhang Y, Tong T, Cui C, Sun J. Dominance of yeast in activated sludge under acidic $\mathrm{pH}$ and high organic loading. Biochem Eng J 2010;52:282-8.

[21] Suntornsuk W. Yeast cultivation in lettuce brine. World J Microb Biot 2000;16(8-9):815-8.

[22] Dan NP, Visvanathan C, Basu B. Comparative evaluation of yeast and bacterial treatment of high salinity wastewater based on biokinetic coefficients. Bioresour Technol 2003;87:51-6.

[23] McGrath JW, Kulakova AN, Kulakov LA, Quinn JP. In vitro detection and characterisation of a polyphosphate synthesising activity in the yeast Candida humicola G-1. Res Microbiol 2005;156:485-91.

[24] Jin B, van Leeuwen J, Yu Q, Patel B. Screening and selection of microfungi for microbial biomass protein production and water reclamation from starch processing wastewater. J Chem Technol Biot 1999;74:106-10.

[25] Paul D, Mukhopadhyay R, Chatterjee BP, Guha AK. Nutritional profile of food yeast Kluyveromyces fragilis biomass grown on whey. Appl Biochem Biotech 2002;97(3):209-18.

[26] Choi MH, Park YH. Production of yeast biomass using waste Chinese cabbage. Biomass Bioenerg 2003;25:221-6.

[27] Stabnikova O, Wang JY, Ding HB, Tay JH. Biotransformation of vegetable and fruit processing wastes into yeast biomass enriched with selenium. Bioresour Technol 2005;96:747-51.

[28] Nigam JN. Single cell protein from pineapple cannery effluent. World J Microb Biot 1998;14:693-6.

[29] Li X, Jia O, Xu Y, Chen M, Song X, Yong Q et al. Optimization of culture conditions for production of yeast biomass using bamboo wastewater by response surface methodology. Bioresour Technol 2009;100:3613-7.

[30] Schneider T, Graeff-Honninger S, French WT, Hernandez R, Merkt N, Claupein W, et al. Lipid and carotenoid production by oleaginous red yeast Rhodotorula glutinis cultivated on brewery effluents. Energy 2013;61:34-43.

[31] Peng W, Huang C, Chen X, Xiong L, Chen X, Chen Y, et al. Microbial conversion of wastewater from butanol fermentation to microbial oil by oleaginous yeast Trichosporon dermatis. Renew Energ 2013;55:31-4.

[32] Zheng S, Yang M, Yang Z, Yang Q. Biomass production from glutamate fermentation wastewater by the co-culture of Candida halophila and Rhodotorula glutinis. Bioresour Technol 2005;96:1522-4.

[33] Zheng S, Yang M, Lv W, Liu F. Study on sludge expansion during treatment of salad oil manufacturing wastewater by yeast. Environ Technol 2001;22(5):533-42.

[34] Daverey A, Pakshirajan K. Pretreatment of synthetic dairy wastewater using the sophorolipid-producing yeast Candida bombicola. Appl Biochem Biotech 2011;163:720-8.

[35] Rydin S, Molin G, Nilsson I. Conversion of fat into yeast biomass in protein-containing waste-water. Appl Microbiol Biotechnol 1990;33(4):473-6.

[36] Lv W, Hesham AEL, Zhang Y, Liu X, Yang M. Impacts of cell surface characteristics on population dynamics in a 
sequencing batch yeast reactor treating vegetable oilcontaining wastewater. Appl Microbiol Biotechnol 2011;90:1785-93.

[37] Kargi F, Dincer A. Use of halophilic bacteria in biological treatment of saline wastewater by fed-batch operation. Water Environ Res 2000;72(2):170-4.

[38] Choi MH, Park YH. Growth of Pichia guilliermondii A9, an osmotolerant yeast, in waste brine generated from kimchi production. Bioresour Technol 1999;70(3):231-6.

[39] Andreishcheva EN, Zvyagilskaya RA. Adaptation of yeasts to salt stress (Review). Appl Biochem Micro 1999;35(3):217-28.

[40] Tondee T, Sirianuntapiboon S, Ohmomo S. Decolorization of molasses wastewater by yeast strain, Issatchenkia orientalis No. SF9-246. Bioresour Technol 2008;99:5511-9.

[41] Kaszycki P, Tyszka M, Malec P, Kołoczek H. Formaldehyde and methanol biodegradation with the methylotrophic yeast Hansenula polymorpha. An application to real wastewater treatment. Biodegradation 2001;12:169-77.

[42] Wu Y, Hu Y, Xie Z, Feng S, Li B, Mi X. Characterization of biosorption process of acid orange 7 on waste brewery's yeast. Appl Biochem Biotech 2011;163:882-94.

[43] Yang $\mathrm{Q}$ Tao L, Yang M, Zhang H. Effects of glucose on the decolorization of Reactive Black 5 by yeast isolates. J Environ Sci-China 2008;20:105-8.

[44] Martins MA, Cardoso MH, Queiroz MJ, Ramalho MT, Campos AM. Biodegradation of azo dyes by the yeast Candida zeylanoides in batch aerated cultures. Chemosphere 1999;38(11):2455-560.

[45] Meehan C, Banat IM, MuMullan G, Nigam P, Smyth F, Marchant R. Decolorization of Remazol Black-B using a thermotolerant yeast, Kluyveromyces marxianus IMB3. Environ Int 2000;26(1-2):75-9.

[46] Lopes M, Araujo C, Aguedo M, Gomes N, Goncalves C, Teixeira JA, et al. The use of olive mill wastewater by wild type Yarrowia lipolytica strains: medium supplementation and surfactant presence effect. J Chem Technol Biot 2009;84(4):533-7.

[47] Galindez-Mayer J, Ramon-Gallegos J, Ruiz-Ordaz N, JuarezRamirez C, Salmeron-Alcocer A, Poggi-Varaldo HM. Phenol and 4-chlorophenol biodegradation by yeast Candida tropicalis in a fluidized bed reactor. Biochem Eng J 2008;38(2):147-57.

[48] Bergauer P, Fonteyne PA, Nolard N, Schinner F, Margesin R. Biodegradation of phenol and phenol-related compounds by psychrophilic and cold-tolerant alpine yeasts. Chemosphere 2005;59:909-18.
[49] Jiang Y, Wen JP, Bai J, Wang DQ, Hu ZD. Pheno] biodegradation by the yeast Candida tropicalis in the presence of m-cresol. Biochem Eng J 2006;29(3):227-34.

[50] Ahuatzi-Chacon D, Ordorica-Morales G, Ruiz-Ordaz N, Cristiani-Urbina E, Juarez-Ramirez C, Galindez-Mayer J. Kinetic study of phenol hydroxylase and catechol 1,2-dioxygenase biosynthesis by Candida tropicalis cells grown on different phenolic substrates. World J Microb Biot 2004;20:695-702.

[51] Pan F, Yang Q, Zhang Y, Zhang S, Yang M. Biodegradation of polycyclic aromatic hydrocarbons by Pichia anomala. Biotechnol Lett 2004;26(10):803-6.

[52] Hesham AEL, Khan S, Liu X, Zhang Y, Wang Z, Yang M. Application of PCR-DGGE to analyse the yeast population dynamics in slurry reactors during degradation of polycyclic aromatic hydrocarbons in weathered oil. Yeast 2006;23(12):879-87.

[53] Groenewald M, Boekhout T, Neuveglise C, Gaillardin C, van Dijck PWM, Wyss M. Yarrowia lipolytica: safety assessment of an oleaginous yeast with a great industrial potential. Crit Rev Microbiol 2014;40(3):187-206.

[54] Robinson PH, Erasmus LJ. Effects of analyzable diet components on responses of lactating dairy cows to Saccharomyces cerevisiae based yeast products: a systematic review of the literature. Anim Feed Sci Tech 2009;149:185-98.

[55] Han H, Zhang Y, Cui C, Zheng S. Effect of COD level and HRT on microbial community in a yeast-predominant activated sludge system. Bioresour Technol 2010;101:3463-5.

[56] Zheng S, Sun J, Han H. Effect of dissolved oxygen changes on activated sludge fungal bulking during lab-scale treatment of acidic industrial wastewater. Environ Sci Technol 2011;45:8928-34.

[57] Quan Y, Han H, Zheng S. Effect of dissolved oxygen concentration (microaerobic and aerobic) on selective enrichment culture for bioaugmentation of acidic industrial wastewater. Bioresour Technol 2012;120:1-5.

[58] Cui C, Zhang Y, Han H, Zheng S. Improvement of FISH-FCM enumeration performance in filamentous yeast species in activated sludge by snailase partial digestion. Yeast 2012;29:111-7.

[59] Elmaleh S, Defrance M, Ghommidh C, Navaro J. Acidogenic effluent treatment in a yeast reactor. Water Res 1996;30(10):2526-9.

[60] Druverfors UA, Schnurer J. Mold-inhibitory activity of different yeast species during airtight storage of wheat grain. FEMS Yeast Res 2005;5:373-8. 